\title{
REPORTS AND DISCUSSION
}

\author{
Shigeru Nakayama
}

\section{How to assess the recent brain reverse phenom- ena: A report of a visit to Taiwan by a Japanese research team}

The so-called "brain drain" has been much discussed in the postwar period, especially with respect to third world nations vis-avis the United States. It has been said that 60 percent of third-world scientists and engineers who hold American degrees never return to home, as financial and research conditions have not matured sufficiently so as to be able to lure back highly-trained scientific personnel. Only in the 1980's, has the phenomenon called 'brain reverse' been noticeable in Asian newly industrialized economies (including Taiwan, Korea, Singapore and Hongkong). It could be argued that for the first time, the industrial sector of the third world has grown to such an extent that it now needs American-educated Ph.D.'s in science and engineering. This event may be historically significant as it constitutes a watershed in the flow of intellectual migration. I would like to discuss, then, this phenomenon in the context of the shift of the international scientific center in history and also the technocratic mechanism involved in the process of promoting such a brain-reverse policy.

\section{The Beginning of Brain Drain Issues}

There has been constant migration of scientists and engineers throughout history. It was, however, with the advent of the Sputnik launching that the United States started a science and technology boom in which foreign scientists were invited to fill the necessary research positions and the word "brain drain" was coined. In the beginning, a flow of scientists from European countries made up for the shortage of research manpower.

Then, in the sixties, it came to be a matter of international politics, when third world governments complained to the U.S. regarding their brain drain at the United Nations. They claimed that their locally-trained and highly-qualified scientists and engineers had been unfairly recruited to the United States and that they should receive financial reparations to meet the cost of their training. 
The U.S. National Science Foundation responded to this and research has been conducted on the international scientific migration for some time. However, the problem was not solved politically, as the issue of the brain drain was largely the matter of individual scientists rather than that of national policy. In principle, the freedom to migrate is an individual human right, which national authorities should not prevent for the sake of national interest. Given this then, no specific political measure was taken for the prevention of brain drain.

\section{East Asians in the Brain Drain}

According to the statistics compiled by UNITAR (the United Nations Institute for Training and Research), the East Asian brain drainees do not constitute any particular deviation from the international average of developing countries in terms of motivation and other factors ${ }^{1}$. In the newly industrialised countries, especially in Taiwan and the Republic of Korea, an American Ph. D. has been more highly evaluated than a Ph. D. from local universities. Good students actively look for opportunities to study abroad for the higher social evaluation upon returning home.

UNESCO statistics (1988) tell us that while the world trend to study abroad declined in the 1980's, Asian overseas students rapidly increased, occupying 46 percent (430.000) of the world total. In parallel with this move of students abroad is a growing demand for higher education at home, especially in China and Korea and many ASEAN countries.

Many students go to the U.S., where more than one third of world total is accepted. China, Taiwan, Japan, India, and the Republic of Korea were the top five nations in terms of sending the most students in 1988-89, followed by Malaysia, Canada and Hong Kong. ${ }^{2}$ Apart from Japan, whose students mostly study abroad for short periods to learn English, the other countries warrant examination for possible brain drain impact.

Chinese students preferred the U.S.
$(75.5 \%)$ as did Koreans $(67.7 \%)$ in $1986^{3}$. Though Japan attracts only a little more than $1 \%$ of the world total of students abroad, the Chinese $(13.1 \%)$ and Koreans $(12.1 \%)$ are increasingly coming to Japan, a distant second to the U.S. For South East Asian students, the order of preferred countries is U.S., Australia and Japan in descending order.

\section{Korean Attempt to Lure Drainees Back in Late 1960's and Early 70's}

Korea's brain reverse has been an organized government effort, rather than a spontaneous phenomenon ${ }^{4}$. President Park Chung-Hee and his technocrats started it in the middle of the 1960's. Precisely, it commenced when KIST (the Korean Institute of Science and Technology) was founded in 1966. In those days, the Korean brain drain rate was an exceptionally high nine-tenth compared to the world average of one-third.

Financial cutbacks in he American scientific world caused by the Vietnam War hit particularly hard on the brain-drainees from the Third World. The Park government, the most efficient and authoritarian technocratic government in postwar (South) Korean history, took advantage of this trend to lure their drainees back home by building KIST in the best part of Seoul.

I visited the Institute in its early phase and found it exiting to listen to the plans of the first director, Dr. Choi Huang-Sup, a Japanese college graduate and U.S. Ph. D., as this sort of brain reverse planning had never existed in Japan. While it looks as though most Korean technocratic policies have been implemented after the example of the Japanese MITI (Ministry of International Trade and Industry), the creation of KIST was certainly the product of the unique initiative of President Park. Dr. Choi told me that he visited the United States and persuaded candidates who showed a willingness to return home.

In the beginning, the returnees to KIST were treated with salaries three times higher that of average university professors. The 
returnees were given freedom in research (not in ideology) and were emancipated from time-honored bureaucratic control. ${ }^{5}$

In the absence of industrial R\&D back in he 1960's, I wondered how these U.S.trained scientist could find appropriate topics of research apart from appropriate technology which was advocated by third world policy makers in those days. The brain reversees were predominantly young $P h$. D. graduates with relatively little work experience $^{6}$, so they may have been able to adapt themselves readily to new native environment.

The technocratic aristocracy of KIST was no longer able to be enjoyed after the assassination of President Park. It was, however, historically significant and came as a shock therapy to the traditional bureaucracy for $R \& D$ to be granted special status. The task of initiating, creating and promoting the trend of brain reverse was thus promoted two decades prior to the need for $R \& D$ in the private sector ${ }^{7}$.

The repatriation of braindrained engineers has been pursued in the private sector since the early 1980's. Since the middle-1980's, following Japanese precedent of R\&D structure, the private sector has dominated ${ }^{8}$ funding of Korean R\&D. Public spending for pursuing repatriation reached a peak in 1985 , since then firm-financed repatriation by large corporations has been fast growing ${ }^{9}$ and the transfer of scientific manpower from the public to private sector has taken place. By 1989 , a total of 1707 were brought back home under the government-sponsored repatriation program, in which 53 percent went to public R\&D institutions ${ }^{10}$.

Even though higher salaries are offered by the private sector, most returnees under the government repatriation policy are still willing to go back to the prestigious public $R \& D$ institutions and the university sector ${ }^{11}$.

\section{Case of Taiwanese Policy}

The brain drain of Taiwan is quite similar to that of Korea or perhaps even more pro- nounced. The ratio between returning and outgoing personnel to the U.S. was only $5 \%$ in the 1960's and $15 \%$ in 1970's. ${ }^{12}$ It went up to $20 \%$ in 1986 and $31 \%$ in $1988^{13}$.

A short after the commencement of the Korean project, the Taiwanese government in the 1970's started brain reverse policy and provided air travel allowances to returning scholars and their dependents ${ }^{14}$.

The Taiwanese government established a law in 1974 to facilitate and promote the "brain reverse" even further. ${ }^{15}$ This involved not only granting return air-fares, but raising the returnee"s salary and research funds for the first two years of his or her appointment at home, and providing an apartment or house. Even the returnee's family received incentives. Most of the returnees have been hired by the university sector and Academia Sinica, the National Central Institute of Research.

There is a clear trend noticeable according to statistics of returned scholars' service in various institutions during 1971-85. In the beginning, more than half of returnees taught at colleges and universities and the number dropped at the end of the period covered to $20 \%$. On the other hand, those who entered private enterprises grew from $5 \%$ to more than $20 \%$ in the same period. In research organizations and other sectors, the percentage remains more or less at a plateau ${ }^{16}$. This trend indicates that while the posts in the prestigious higher education sector tended to be filled up, industrialization promoted a demand for highly-trained scientific manpower in private sector enterprises.

In 1983, the government and private sector launched a new program to recruit hi-tech experts abroad. This was to attract more experienced experts by providing them with the same pay that they enjoyed abroad.

Since 1989, more returnees entered the private sector than the academic and public sectors, as the positions in the latter are limited and hard to expand whereas the former has undergone rapid expansion. However, as business activity declines, they may turn to the public sector ${ }^{17}$.

In recent years, more and more govern- 
ment agencies as well as private organizations seek personnel holding doctoral degrees, especially in the engineering field ${ }^{18}$.

\section{Research Visit to Taiwan}

For the reasons stated previously, a research team has been organized to visit newly industrialised countries to observe, interview and attempt to account for this significant change. Most typical is Taiwan, where the rapid development of a local computer industry may have induced brain drainers to return home.

In the meantime, a worldwide economic recession in the early 1990's has also hit East Asia. We heard that more than half of returnees had been retrenched in a Taiwanese automobile factory. Nevertheless, we carried out what we planned to do. it was in early 1994 when a Japanese study team to investigate scientific manpower headed by myself visited Taiwan and interviewed returnees in universities and the Hsinchu sciencebased industrial park, as well as government officials in Taipei.

Those interviewees, who were attracted back in the early days of government brain reverse policy, were mostly working in the academic sector. Middle-aged researchers, who worked in public R\&D institutions situated in the Hsinchu science park were academically oriented. Lastly, we found that government committee people and bureaucrats were primarily interested in returnees in the academic and public sector. They were, in a sense, prejudiced against private sector activities. It is rather unusual to find American-educated Ph. D.'s working in the industrial sector in Taiwan. The brain reverse policy of the government has thus tended to be an educational policy rather than a MITIstyle industrial policy per se.

The "brain reverse' law was discontinued last year for national universities, as migrant Ph. D.'s in the U.S. have recently found job security, namely tenure, difficult to obtain. An increasing number of them are willing to go home, as long as positions in the pres- tigious national universities, which are by now mostly filled up, are open to them. The government now finds it unnecessary to encourage them by granting various privileges. But less prestigious private universities have been disappointed by the scrapping of the law, as they have been recruiting brain reversers by using it to their advantage.

It is unfortunate that we were unable to interview private sector people. They were on this occasion peripheral to our main concern of governmental brain reverse policy. We had, however, a general impression, while at the Hsinchu science-based industrial park, that the private sector is still very much under the patronage and control of the public sector. In contrast, the heyday of MITI was already over by the 1970's in Japan.

We cannot yet say that this necessarily constitutes an historical watershed. One thing is clear however. From the viewpoint of the Taiwanese government, the brain drain phenomenon no longer constitutes a threat but rather a gain in terms of Taiwan's need to train high-level manpower for national development and in terms of $\operatorname{cost}^{19}$, that is as long as Taiwanese Ph. D.'s return home after finishing their graduate education in the U.S.

\section{Privatization of Technocratic Government Policy}

It must be pointed out that repatriated returnees were most needed in newly industrialised economies for the development of import-substitute and export-oriented technology rather than appropriate technology for the domestic market.

Now there is a need to repatriate welltrained and experienced engineers rather than Ph. D.'s. Training for the prestigious academic and public sectors does not satisfy the needs of practical technicians and engineers in the private sector. Skill-based, rather than purely degree-oriented, repatriation should receive closer attention ${ }^{20}$, if technology transfer from public to private 
sector is to be a goal of science policy. In this sense, the Korean government policy shift from permanent repatriation to temporary repatriation seems to be a rational choice $^{21}$, as permanent dependence on the government budget to recruit highly talented personnel into the private sector is not a healthy policy if one is to promote privatization and also internalization of industrial technology.

Because of the current business slum, it seems that even the highly trained scientific professionals find difficulty in getting jobs in the private sector, but the role of government in brain reverse policy in both Korea and Taiwan is nearly over. The next step will be to internalize the training system so as to raise endogenous technicians and eventually professionals in order to catch up with U.S. and Japan.

If we compare the Japanese experience during the 1950's and early 60's with that of Korea and Taiwan from the 1970's on, we find certain parallels and differences.

A number of postwar Japanese scientist and engineers visited the U.S. to fill the gap of scientific information created during the wartime isolation period and brought back home indispensable information and knowhow for innovation. There was no particular brain reverse policy on the part of government, save MITl's guidance to strategic industry and technology. There was no significant brain drain from Japan to the U.S., as returnees were expected to assist in technology transfer upon arriving home in all sectors.

In contrast, the Korean and Taiwan governments initiated repatriation with clearly formulated brain reverse policies. At least from the viewpoint of the nation-state, such an attempt proved to be successful in view of the later economic development based on export-oriented technology. We may be able to conclude that their high technology industry has taken off to the extent that governmental measure of brain reverse policy is no longer necessary. Future problems still remain of how successfully they could privatize and perpetuate their market-oriented technology without further governmental assistance and control.

\section{Future of Asian Scientists Reversed}

Throughout the history of science, the center of scientific activity has continually moved from ancient Babylonia down to the 20th century USA. Accordingly, scientific professionals migrated from the periphery towards the center for training and research. There has been some form of brain drain any time in history.

Academic science is basically individualistic and open activities of scientists. As far as academic science is concerned, free migration must be, in principle, guaranteed. For public and private science, however, national and corporate policies determine the direction of professional migration. In this respect, the brain reverse policy of Korea since the mid-1960's, and that of Taiwan since the 1970's, undoubtedly played an important role in determining the direction of future scientific and technological development.

Although the center of academic science will stay in the U.S. for the foreseeable future, things will be more complicated in the case of industrialized science, as it is not geared to academic publication but is primarily a closed activity confined to the corporate sector. Since industrialized science is not the exclusive matter of the academic community of high talents, English may not be the commonly used language but the native vernacular languages will be more important in training and communicating with to the technicians and skilled scientific workers who are badly needed.

Then, the center of manufacturing and of industrialized science will shift from U.S. to Japan, and then on to East Asia still more easily and rapidly than academic science as in the case of brain reverse in recent East Asia. Or, to be more precise, it is not necessarily a function of the center in industrialized science, as it existed in the case of academic science.

Furthermore, with the increasing privati- 
zation of science in the post-Cold War World, national boundaries will become more prevalent in the scientific community.

On the other hand, privatization will widen the gap in remuneration between secondary and tertiary industries. In the de-developed area like Europe, and the USA followed by Japan, the younger generation tend to seek affluence and avoid hard-working scientific and technological careers, which is more competitive with the youth from developing countries. In order to prolong industrial hegemony, USA and Japan will look to Asian youth in order to recruit scientific workers in to their transnational corporations.

From the viewpoint of private enterprises, it means competition between U.S.-Asia and the Japan-Asia manpower multinationals not only in terms of technical acumen but also in recruiting highly talented scientific workers.

Finally, from the viewpoint of ordinary citizens, transnationalistic environment will hopefully support and promote the basic human rights of the migration of scientists and of people in general.
3. UNESCO Statistical Yearbook (1988)

4. Bang-Soon L. Yoon, "Reverse Brain Drain in South Korea: State-led Model" Studies in Comparative International Development vol, 27, no. 1, (Spring 1992): 4

5. Yoon 1992: 17

6. Yoon 1992: 11.

7. Yoon 1992: 19.

8. Yoon 1992: 9.

9. Yoon 1992: 13 .

10. Yoon 1992: 10

11. Yoon 1992: 11

12. Shirley L. Chang, "Causes of Brain Drain and SoIutions: The Taiwan Experience" Studies in Comparative International Development vol. 27, no. 1, (Spring 1992): 28.

13. Otsuka, Yutaka "Taiwan kara mita Nihon ryugaku (Studying in Japan from the Taiwanese Viewpoint)" Koto kyoiku kenkyu kiyo (Bulletin of the Institute for higher education) no. 12, (December 1990): 98.

14. Chang 1992: 39.

15. The Ministry of Education (Taiwan) 1991 Taiwan (The Ministry of Education, Taiwan Government), Chiaoyu fachan shihliao (Historical sources of the educational development in Taiwan, Science and technology), 1991: 673.

16. Chang 1992: 39.

17. Interview with Ms. Chao Hsialin in Nakayama, Shigeru (rep), Kodo gijutsu shakai ni okeru kagaku gijutsu manpawa no mondai (Scientific manpower in high technology society), in Kodo gijutsu shakai no pa-supekuchibu (Perspective of High Technology Society), 1992 grant research report, (no. 04210128 ), March 1993, p. 86.

18. Chang 1992: 40-42.

19. Chang 1992: 42.

20. Yoon 1992: 23.

21. Yoon 1992: 23

\section{NOTES}

1. (Glaser and Habers 1978: 227-244) William A. Glaser and G. Christopher Habers, "The Migration and Return of Professionals" International Migration Review vol. 12 (1978): 227-244.

2. Institute of International Education, Open Doors, 1991/1992 (1992).
Shigeru Nakayama

STS Center

Kanagawa University

2946 Tsuchiya, Hiratsuka

Kanagawa

Japan 